\title{
Evaluation of wound healing effect of petroleum ether and methanolic extract of Abelmoschus manihot (L.) Medik., Malvaceae, and Wrightia tinctoria R. Br., Apocynaceae, in rats
}

\author{
Pritam S. Jain, * Sanjay B. Bari
}

\author{
Department of Pharmaceutical Chemistry, R. C. Patel Institute of Pharmaceutical Education and Research, \\ Shirpur Dist. Dhule, Maharashtra, 425 405, India.
}

\begin{abstract}
RESUMO: "Avaliação do efeito de cicatrização dos extratos de éter de petróleo e metanol de Abelmoschus manihot (L.) Medik., Malvaceae, e Wrightia tinctoria R. Br., Apocynaceae, em ratos". Nos últimos anos, o estresse oxidativo e radicais livres têm sido implicados na cicatrização. Abelmoschus manihot (L.) Medik., Malvaceae e Wrightia tinctoria R. Br., Apocynaceae, plantas utilizadas na medicina Ayurveda, possuem propriedades antiinflamatórias e antimicrobianas. $\mathrm{O}$ presente estudo foi realizado para avaliar o potencial dos extratos de éter de petróleo e metanólico na cicatrização de feridas em ratos Wistar. Os ratos foram divididos em seis grupos com seis animais cada. O grupo 1 foi utilizado como controle, o grupo 2 recebeu a droga padrão e os outros quatro grupos foram tratados com duas doses diferentes de cada um dos extratos de A. manihot e W. tinctoria. Os parâmetros de cicatrização foram avaliados através da incisão feridas em ratos tratados com extrato, padrões e controles. Ambas as doses dos extratos de éter de petróleo e metanólico aumentaram significativamente força de ruptura da ferida quando comparados ao grupo controle.
\end{abstract}

Unitermos: Abelmoschus manihot, Wrightia tinctoria, atividade cicatrizante.

\begin{abstract}
In recent years, oxidative stress and free radicals have been implicated in impaired wound healing. Abelmoschus manihot (L.) Medik., Malvaceae, and Wrightia tinctoria R. Br., Apocynaceae, plants widely used in Ayurveda, possesses anti-inflammatory and antimicrobial properties. The present study was undertaken to assess the potential of petroleum ether and methanol extracts in wound healing in Wistar albino rats. The rats were divided into six groups of six animals each. Group 1 is normal wounded control, group 2 received standard drug and the other four groups were treated with two different doses each of petroleum ether and methanol extract of $A$. manihot and $W$. tinctoria. The wound healing parameters were evaluated by using incision wounds in extract-treated rats, standard and controls. Both the doses of petroleum ether and methanol extract significantly increased wound breaking strength when compared with the control group.
\end{abstract}

Keywords: Abelmoschus manihot, Wrightia tinctoria, wound healing activity.

\section{INTRODUCTION}

Acute wounds normally heal in a very orderly and efficient manner characterized by four distinct but overlapping phases: Hemostasis, inflammation, proliferation, and remodeling (Robert \& Melissa, 2004). Approximately 225,000 spinal chord injury patients in US, $60 \%$ out of these patients develops pressure ulcers and annual cost estimate ranges from $\$ 14,000$ to $\$ 25,000$ per patient. Therefore national expenditure for costs related to the care of patients with pressure ulcer is over $\$ 1.3$ billion per year (Cockbill, 2002). Wound, one of the common clinical conditions has been targeted for exhaustive investigation so as to identify the ways and means of promoting the healing process. Wound healing involves a complex series of interaction between different cell types, cytokines mediators and the extracellular matrix (Ehrlich \& Hunt, 1968).

Abelmoschus manihot (L.) Medik., Malvaceae (Anonymous, 1976) is a large annual erect hairy plant, 1.2-1.8 m. high. It is native to China, introduced into India, near Calcutta and in coastal areas of Maharashtra. The plants mucilage contains polysaccharides and proteins (Kirtikar \& Basu, 1994). The flower contain quercetin-3robinoside, quercetin-3'-glucoside, hyperin, myrecetin and anthocyanins (Lai et al., 2009). The saturated acids and liquid acids such as linoleic and oleic acids were isolated from the seed fat and unsaponifiable matters. The different 
chromatographic methods have been developed on the flavones present in the plant (Liang et al., 2007, Li et al., 2006). The ethanol extract of flower was screened for antiviral activity, and it was observed that the hyperoside shown significant anti HBV activity (Linlin et al., 2007). The flavones present in the plant showed preventive effect in the injury (Liu et al., 2009, Wen \& Chen, 2007). The leaves were tested on bone loss in ovarectomised rats and it was observed that it was able to prevent the ovariectomy induced femoral osteopenia (Puel et al., 2005) modulatory effect of total flavone of Abelmoschus manihot (TFA) on NMDA-activated current (INMDA) was investigated in cultured rat hippocampal neurons using the wholecell patch-clamp technique. TFA rapidly and reversibly inhibited the INMDA in a concentration-dependent manner (Xin-ping et al., 2006).

Wrightia tinctoria R. Br., Apocynaceae, is a small deciduous tree, generally up to $1.8 \mathrm{~m}$ tall and often under $60 \mathrm{~cm}$ girth, sometimes up to $7.5 \mathrm{~m}$ high, distributed all over India. Four uncommon sterols, desmosterol, clerosterol, 24-methylene-25-methylcholesterol and 24-dehydropollinastanol, in addition to several usual phytosterols, were also isolated and identified (Akihisa et al., 1988). The wrightial, a new terpene and other phytoconstituents such as cycloartenone, cycloeucalenol were isolated identified by fractionation of methanol extract of the immature seed pods (Ramchandra et al., 1993). The hexane extract of seed pods of $W$ tinctoria was saponified and non saponifiable matter was fractionated with methanol gave a colourless substance, oleanolic acid (Rao \& Rao, 1968). The five flavonoid compounds, indigotin, indirubin, tryptanthrin, isatin and rutin were isolated and identified from the leaves (Muruganadam et al., 2000). The unsaponifiable matter extracted from bark by petroleum ether extract was fractionated with methanol to yield a triterpenes like $\beta$-sitosterol and $\beta$-amyrin, wrigatiadione (Warrier, 1996). The ursolic acid has been also isolated from the chloroform extract of seed pods (Rao \& Rao, 1966).

The bark is used as stomachic and in the treatment of abdominal pain and skin diseases (Shah et al., 1988), as antidysenteric, antidiarrhoeal and antihaemorrhagic. The bark is used in flatulence and bilious affections. A decoction of the leaves and bark is taken as a stomachic and in the treatment of abdominal pain (Joshi et al., 1980). The dried and ground bark is rubbed over the body in dropsy. The plant is used in Ayurveda, Unani and Siddha medicines as astringent, febrifuge and tonic (Tomar \& Singh, 1990). The seeds are said to possess antipyretic, analgesic, and anti-inflammatory activity (Ghosh et al., 1985).

Keeping in view the tremendous pharmacological activities and a wealth of available literature, Abelmoschus manihot and Wrightia tinctoria, may be utilized to alleviate the symptoms of a variety of diseases as evident from pre-clinical data (Nigam et al., 2006a). Thus it appears that different mechanisms like free radical scavenging, metal chelation as well as immune modulation may act at different levels individually or in combination to bring about the wound healing effects of this medicinal plant.

From another viewpoint using animals for healing it is now universally acknowledged that maggot therapy can be used successfully to treat chronic, longstanding, infected wounds, which have previously failed to respond to conventional treatment. Such wounds are typically characterized by the presence of necrotic tissue, underlying infection and poor healing (Nigam et al., 2006b). Maggot therapy employs the use of freshly emerged, sterile larvae of the common green-bottle fly, Phaenicia (Lucilia) sericata and is a form of artificially induced myiasis in a controlled clinical situation. Maggot therapy has the following three core beneficial effects on a wound: debridement, disinfection and enhanced healing (Gupta et al., 2002).

\section{MATERIAL AND METHODS}

\section{Plant material}

The woody stem of Abelmoschus manihot (L.) Medik., Malvaceae, and Wrightia tinctoria R. Br., Apocynaceae, were collected during the month of MayJune from the Toranmal Hills of Maharashtra. The plant was taxonomically identified by Professor Dr. D. A. Patil, HOD Botany Dept, SSVPS College, Dhule, North Maharashtra University, Jalgaon, M. S., India (Figure 1)
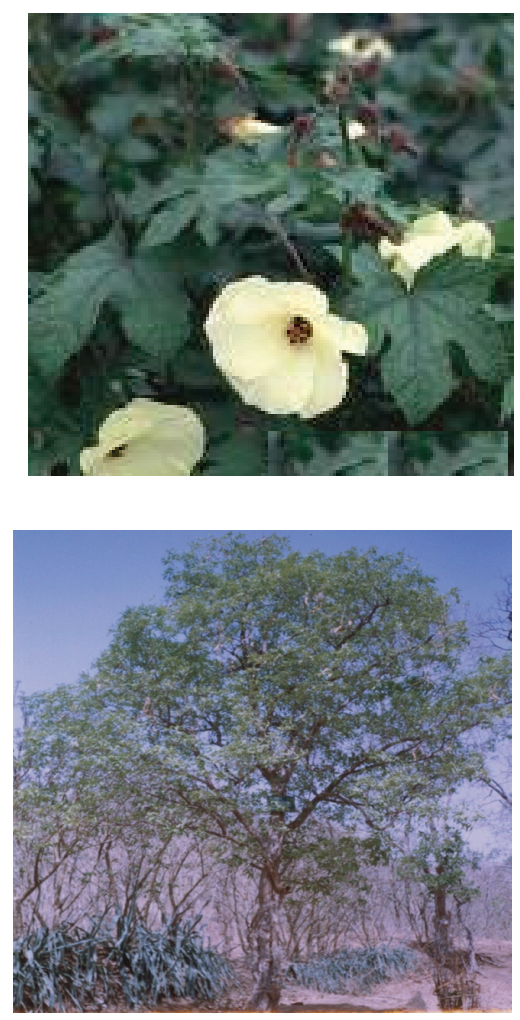

Figure 1. Aspect of Abelmoschus manihot (L.) Medik., Malvaceae and Wrightia tinctoria R. Br., Apocynaceae 


\section{Preparation of extracts}

The woody stems of $A$. manihot and $W$. tinctoria were dried in shade and powdered. The woody stem powders $(500 \mathrm{~g})$ were extracted by petroleum ether and methanol using soxhlet apparatus at $60-75^{\circ} \mathrm{C}$. Extract was concentrated by evaporation (Suffness et al., 1978). The yield was about 1-5\%. The semisolid extract was dissolved in saline by using gum acacia as a vehicle during the study.

\section{Phytochemical evaluation of Abelmsochus manihot and Wrightia tinctoria (Harborne, 1998)}

\section{Test for steroid and triterpenoids}

Salkowski reaction: A small quantity of petroleum ether extract of both the plants was dissolved in chloroform and a few drops of concentrated sulfuric acid were added to the solution. For extract of both the plants, a reddish color was seen in the upper chloroform layer.

Liebermann-Burchard reaction: A small quantity of petroleum ether extract of both the plants was dissolved in chloroform and a few drops of concentrated sulfuric acid were added to it followed by the addition of 2-3 drops of acetic anhydride. Solution for extracts of both the plants turned violet blue and finally green.

\section{Test for flavonoids}

Shinoda test: To dried methanol extract of both the plants, added $5 \mathrm{ml} 95 \%$ ethanol, few drops concentrated $\mathrm{HCl}$ and $0.5 \mathrm{~g}$ magnesium turnings. Pink color was observed.

\section{Preparation of ointment}

The ointment of the petroleum ether and methanolic woody stem extracts of $A$. manihot and $W$. tinctoria, were prepared in concentration of $5 \%(\mathrm{w} / \mathrm{w})$ and $10 \%(\mathrm{w} / \mathrm{w})$ using simple ointment base.

\section{Rats}

Albino Wistar rats if either sex having weight of 200-250 g were procured from R. C. Patel Institute of Pharmaceutical Education and Research, Shirpur. The rats were housed in polypropylene cages and maintained under standard conditions (12 h light and dark cycles, at $25-27{ }^{\circ} \mathrm{C}$ and $35-60 \%$ humidity). Standard palletized feed and water were provided ad libitum. The experimental protocol was subjected to scrutiny of Institutional Animal Ethical Committee for experimental clearance ( $\mathrm{N}^{\circ}$. IAEC/ RCPIPER/UA/2009). The animals were divided into six groups of six animals each and were daily administered the extract of $A$. manihot and $W$. tinctoria.

\section{Abelmoschus manihot}

Group I: Control group treated with simple ointment

Group II: Positive (standard) control treated with Povidone Iodine Ointment

Group III: 5\% Ointment of woody stem petroleum ether extract of A. manihot (PEA)

Group IV: $10 \%$ Ointment of woody stem petroleum ether extract of A. manihot (PEA)

Group V: $5 \%$ Ointment of methanol extract of $A$. manihot (MEA)

Group VI: 10\% Ointment of methanol extract of $A$. manihot (MEA)

\section{Wrightia tinctoria}

Group I: Control group treated with simple ointment Group II: Positive (standard) control treated with Povidone Iodine Ointment

Group III: 5\% Ointment of woody stem petroleum ether extract of $W$. tinctoria (PEW)

Group IV: $10 \%$ Ointment of woody stem petroleum ether extract of $W$. tinctoria (PEW)

Group V: $5 \%$ Ointment of methanol extract of $W$. tinctoria (MEW)

Group VI: $10 \%$ Ointment of methanol extract of $W$. tinctoria (MEW)

\section{Experimental procedure}

The wounding procedure was carried out using 1 $\mathrm{mL}$ of ketamine $(10 \mathrm{mg} / \mathrm{kg}$ body weight) anesthetized rats in incisional wound model. The ointment preparations and standard Iodine-Povidone ointment (CIPLADINE, Cipla Ltd.) were applied topically to the wound area. On the 9th post wounding day, the sutures were removed and skin breaking strength was measured on 10th post wounding day by continuous water flow technique.

\section{Wound model incision wound}

Two paravertebral incisions (6 cm long) were made through the full thickness of the skin on either side of the vertebral column (Ehrlish \& Hunt, 1969). Wounds were closed with interrupted sutures, $1 \mathrm{~cm}$ apart. The sutures were removed on the 7th day. Wound breaking strength (WBS) was measured on the 10th post-wounding day (Lee, 1968).

Determination of wound breaking strength (Lee, 1968)

Rats were secured to the operation table and a line was drawn on either side of the wound $3 \mathrm{~mm}$ away from the wound. Two allice forceps were firmly applied on to the line facing each other. One of the forceps was fixed, while the other was connected to a freely suspended lightweight polypropylene graduated container through a string run over to a pulley. Water was allowed to flow 
from the reservoir slowly and steadily into the container. A gradual increase in weight was transmitted to the wound site pulling apart the wound edges. As and when the wound just opened up, the water flow was arrested and the volume of water collected in the container (approximately equal to its weight) was noted. Three readings were recorded for a given incision wound and the procedure was repeated on the wound on the contralateral side. The average reading of the group was taken as an individual value of breaking strength. Mean value gives the breaking strength for a given group.

\section{Acute toxicity studies}

Healthy rats $(n=6)$ were orally fed with increasing doses ( $400 \mathrm{mg} / \mathrm{kg}$ to $6 \mathrm{~g} / \mathrm{kg}$ body weight) of extracts for 14 days.

\section{Statistical Analysis}

The results were analyzed using one way analysis of variance (ANOVA) with Dunett's multiple comparison test. $p$-values $<0.05$ were considered statistically significant.

\section{RESULTS}

The phytochemical screening of petroleum ether and methanolic extracts of both the plants showed positive test for steroids, triterpenoids and flavonoids. The doses up to $2 \mathrm{~g} / \mathrm{kg}$ body weight did not produce any toxicity and mortality. The woody stem extracts of Abelmoschus manihot and Wrightia tinctoria showed significant wound healing activity in incisional wound model (Figure 2 and 3). In incisional wound model, (Table 1 and 2 ) indicates skin breaking strength (Tensile strength), the $5 \%$ and $10 \%$ petroleum ether and methanol extract ointment treated group shows significant $(p<0.01)$ increase in tensile strength but standard treated animals showed better skin breaking strength as compared to the control group. IodinePovidone ointment used as standard for the study.

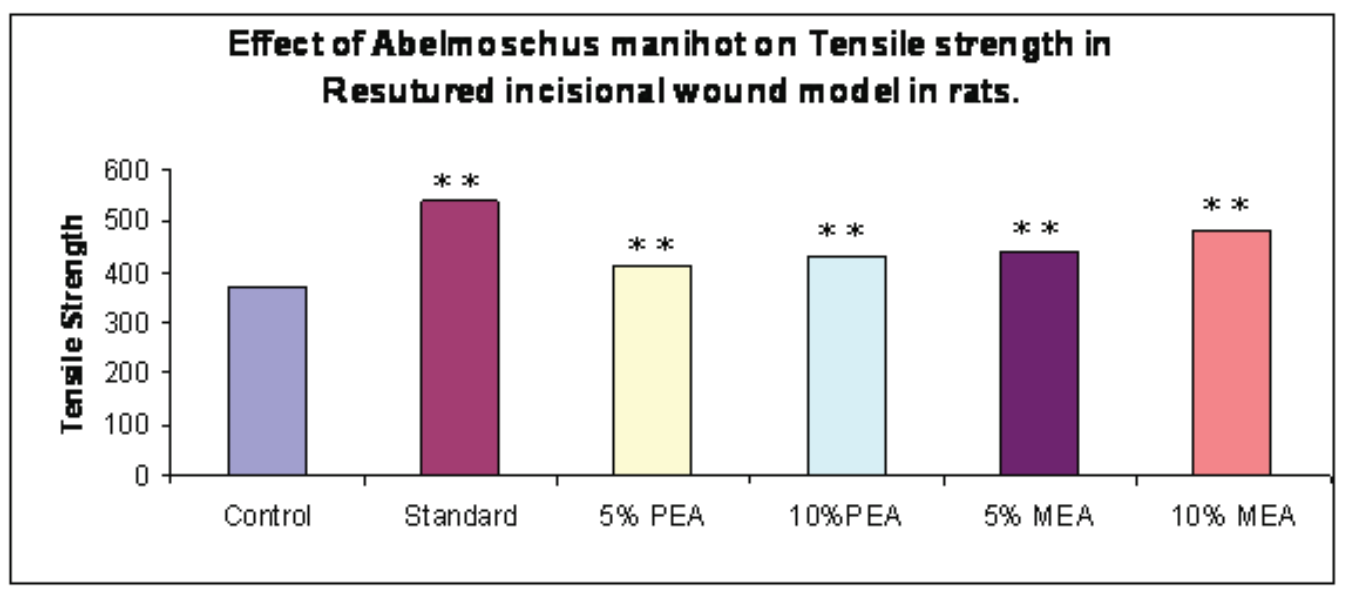

Figure 2. Wound healing activity of extracts of Abelmoschus manihot in incisional model.

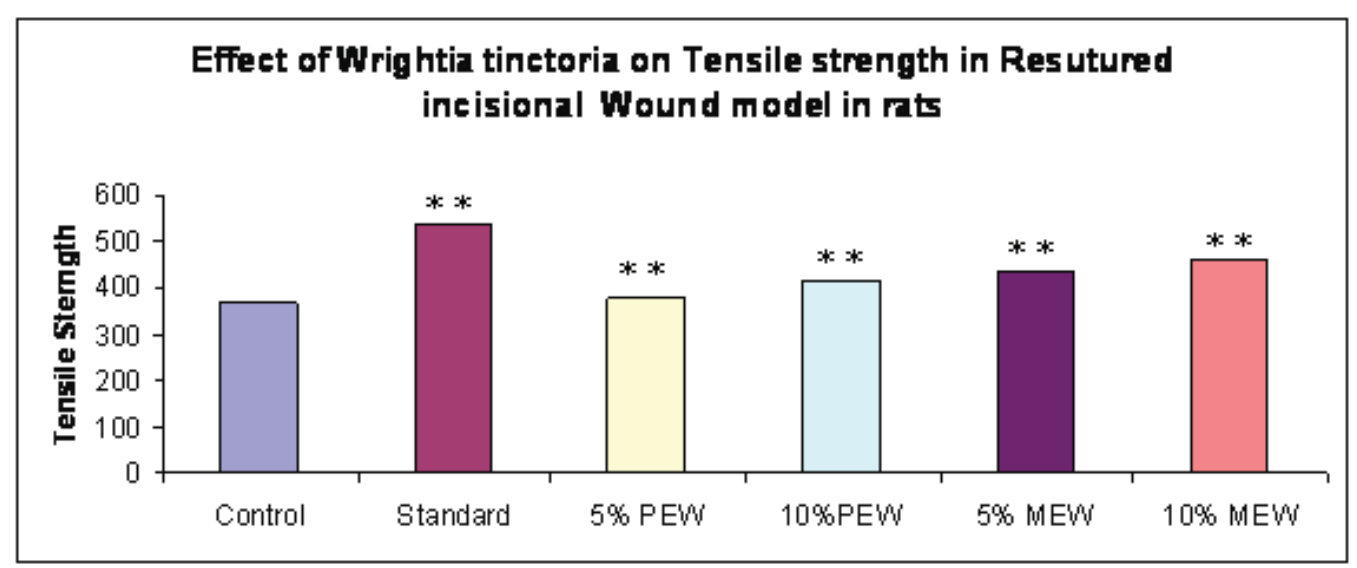

Figure3. Wound healing activity of extracts of Wrightia tinctoria in incisional model. 
Table 1. Effect of extracts of Abelmoschus manihot on tensile strength $(\mathrm{g})$ in resutured incisional wound model in rats.

\begin{tabular}{ccccccc}
\hline Animal No. & Control & Standard & $5 \%$ PEA & $10 \%$ PEA & $5 \%$ MEA & $10 \%$ MEA \\
\hline 1 & 367.5 & 514.5 & 391.0 & 453.0 & 431.5 & 469.5 \\
2 & 370.5 & 549.5 & 408.5 & 435.0 & 448.5 & 487.5 \\
3 & 379.5 & 537.0 & 410.0 & 429.5 & 457.5 & 490.0 \\
4 & 364.0 & 557.5 & 389.5 & 432.5 & 443.0 & 473.5 \\
5 & 380.0 & 526.0 & 416.5 & 419.0 & 442.5 & 471.5 \\
6 & 340.0 & 540.5 & 415.5 & 415.0 & 435.5 & 479.0 \\
\hline Mean & 366.9 & $537.5^{* *}$ & $405.2^{* *}$ & $430.7^{* *}$ & $443^{* *}$ & $478^{* *}$ \\
Std. Error & 5.988 & 6.363 & 4.885 & 5.489 & 3.782 & 3.505 \\
\hline
\end{tabular}

Values are Mean \pm S.E. $(\mathrm{n}=6)$; ANOVA followed by Dunnett's Multiple Comparison test. $p$-values are $p<0.01 * *$ as compare with control. Where, 5\% PEA- 5\% ointment of petroleum ether extract of Abelmoschus manihot; 10\% PEA- $10 \%$ ointment of petroleum ether extract of Abelmoschus manihot; 5\% MEA- 5\% ointment of methanolic extract of Abelmoschus manihot; 10\% MEA- 10 \% ointment of methanolic extract of Abelmoschus manihot.

Table 2. Effect of extracts of Wrightia tinctoria on tensile strength (g) in resutured incisional wound model in rats.

\begin{tabular}{|c|c|c|c|c|c|c|}
\hline Animal $\mathrm{N}^{\circ}$ & Control & Standard & $5 \%$ PEA & $10 \%$ PEA & $5 \%$ MEA & $10 \%$ MEA \\
\hline 1 & 367.5 & 514.5 & 371.0 & 433.0 & 421.5 & 449.5 \\
\hline 2 & 370.5 & 549.5 & 388.5 & 418.0 & 434.5 & 468.5 \\
\hline 3 & 379.5 & 537.0 & 390.0 & 419.5 & 447.5 & 471.0 \\
\hline 4 & 364.0 & 557.5 & 370.5 & 420.5 & 437.0 & 465.5 \\
\hline 5 & 380.0 & 526.0 & 386.5 & 409.0 & 432.5 & 461.5 \\
\hline 6 & 340.0 & 540.5 & 368.5 & 408.0 & 428.5 & 459.0 \\
\hline Mean & 366.9 & $537.5^{* *}$ & $379.2 * *$ & $418.0 * *$ & $433.6^{* *}$ & $462.5^{* *}$ \\
\hline Std. Error & 5.988 & 6.363 & 4.139 & 3.717 & 3.555 & 3.160 \\
\hline
\end{tabular}

Values are Mean \pm S.E. ( $\mathrm{n}=6$ ); ANOVA followed by Dunnett's Multiple Comparison test. $p$-values are $p<0.01 * *$ as compare with control. Where, 5\% PEW- 5\% ointment of petroleum ether extract of Wrightia tinctoria; $10 \%$ PEW- $10 \%$ ointment of petroleum ether extract of Wrightia tinctoria; $5 \%$ MEW- 5\% ointment of methanolic extract of Wrightia tinctoria; $10 \%$ MEW- $10 \%$ ointment of methanolic extract of Wrightia tinctoria.

\section{DISCUSSION}

The results from phytochemical screening showed that petroleum ether and methanolic extracts of woody stems of Abelmoschus manihot and Wrightia tinctoria mainly contain steroids, triterpenoids and flavonoids. There was reported that flavonoids, saponins like antioxidants showed significant wound healing activity. The enhanced wound healing may thus be due to the free-radical scavenging action of the plant, and the enhanced level of antioxidant enzymes in the tissues. In case of Resutured incisional wound model we were using petroleum ether and methanolic extracts of woody stems. In such type of model wound healing by primary intention. In this model, the increase in tensile strength of treated wounds may be due to the increase in collagen concentration and stabilization of the fibers (Udupa et al., 1995). Resutured wound was checked for the tensile strength. All the formulations i.e. $5 \%$ and $10 \%$ of both the plants showed significant increase in tensile strength. It may due to the enhanced action of myofibroblasts which are mainly responsible for the elasticity of tissue.

\section{REFERENCES}

Akihisa T, Ishtiaque A, Singh S, Tamura T, Matsumoto M 1988. $14 \alpha$-Methylzymosterol and other sterols from Wrightia tinctoria seeds. Phytochemistry 27: 3231-3234.

Anonymous 1976. The wealth of India: Raw Materials. Publication and Information Directorate, CSIR, New Delhi, India.

Cockbill S 2002. Wounds the healing process. Hosp Pharmacist 9: 255-259.

Ehrlich HP, Hunt TK 1968. Effect of cortisone and vitamine A on wound healing. Ann Surg 167: 324-328.

Ehrlich HP, Hunt HK 1969. Effect of anabolic steroid on tensile strength of a healing wound. Ann Surg 170: 203-208.

Harborne JB 1998. Phytochemical Methods: A guide to modern techniques of plant analysis, $3^{\text {rd }}$ ed., Springer, London, pp. $129-138$

Ghosh D, Thejomoorthy P, Veluchamy G 1985. Antiinflammatory, analgesic and antipyretic activities of oil Siddha medicine. Bull Med Ethano Biol Res 6: 141-154

Gupta SK, Prakash Jai, Srivatsava Sushma 2002. Validation of traditional claim of Tulsi, Ocimum sanctum Linn. As a medicinal plant. Indian J Exp Biol 40: 765-773.

Joshi MC, Patel MB, Mehta PJ 1980. Some folk medicines of 
Dangs, Gujarat state. Bull Med Ethnobot Res 1: 8-24.

Kiritikar KR, Basu DB 1994. Indian Medcid Plants, Vol. 3. 2nd Ed., Allahabad India, pp. 1606-1609, 1783-1792.

Lai X, Liang H, Zhao Y, Wang B 2009. Simultaneous determination of seven active flavonols in the flowers of Abelmoschus manihot by HPLC. J Chromatogr Sci 47: 206-210.

Lee KH 1968. Studies on the mechanism of action of salicylates 3. Effect of vitamin A on wound healing retardation of aspirin. J Pharmacol Sci 57: 1238-40.

Liang H, Lai X, Zhao Y, Bai Y, Wang B, Guo D 2007. SPEHPLC method for the determination of four flavonols in rat plasma and urine after oral administration of Abelmoschus manihot extract. J Chromatogr B Analyt Technol Biomed Life Sci 852: 108-114.

Li C, Yue DK, Sun YF 2006. Chemical constituents from roots of Ficus hirta. J Chinese Mat Med 31: 131-133.

Linlin WU, Xinbo Y, Zhengming H, Hezhi L, Guangxia WU 2007. In vivo and in vitro antiviral activity of hyperoside extracted from Abelmoschus manihot (L.) Medik. Acta Pharmacol Sin 28: 404-409.

Liu M, Jiang QH, Hao JL, Zhou LL 2009. Protective effect of total flavones of Abelmoschus manihot (L.) Medik. against poststroke depression injury in mice and its action mechanism. Anat Rec 292: 412-422.

Muruganadam AV, Bhattacharya SK, Ghosal S 2000. Indole and flavonoid constituents of Wrightia tinctoria and $W$. tomentosa and W. coccinea. Indian J Chem B 39: 125131.

Nigam Y, Bexfield A, Thomas A, Ratcliffe NA 2006a. Maggot therapy: the science and implication for CAM part I-history and bacterial resistance. Evid Based Complement Alternat Med 3: 223-227.

Nigam Y, Bexfield A, Thomas A, Ratcliffe NA 2006b. Maggot therapy: the science and implication for CAM part IIMaggots Combat Infection. Evid Based Complement Alternat Med 3: 303-308.

Puel C, Mathey J, Davicco MJ, Lebecque P, Chanteranne B, Horcajada MN, Coxam V 2005. Preventive effect of Abelmoschus manihot (L.) Medik. on bone loss in the overiectomised rats. J Ethnopharmacol 99: 55-60.

Ramchandra P, Basheermiya M, Krupadanam GLD, Srimannarayana G 1993. Wrightial, a new terpene from Wrightia tinctoria. J Nat Prod 56: 1811-1812.

Rao MN, Rao EV, Rao VS 1966. Triterpenoid components of the leaves and pods of Wrightia tinctoria R. Br. Curr Scien India 35: 518-519.

Rao MN, Rao EV 1968. Occurance of oleanolic acid in the pods of Wrightia tinctoria R. Br. Curr Sci India 22: 645-646.

Robert F, Melissa CE 2004. Wound healing: an overview of acute, fibrotic and delayed healing. Front Bioscience 9: 283-289.

Shah GL, Gopal GV 1988. Ethnomedical notes from the tribal inhabitants of the north Gujarat (India). J Eco Tox Bot 6: 193-221.

Suffness M, Douros J 1978. New natural products of interest under development at the National Cancer Institute. Cancer Chemother Pharmacol 1: 91-100.

Tomar GD, Singh RN 1990. Treatment of hepatocellular jaundice with kalmegh (Andrographis paniculata). Aryavaidyan 2: 156-162.

Udupa AL, Kulkarni DR, Udupa SL 1995. Effect of Tridax procumbans extracts on wound healing. Int JPharmacogn 33: $37-40$.
Warrier PK, Nambier VPK, Raman K 1996. Indian Medicinal Plants. Orient Longman Ltd., Madras.

Wen JY, Chen ZW 2007. Protective effect of pharmacological preconditioning of total flavones of Abelmoschus manihot on cerebral ischemic reperfusion injury in rats. Am J Chin Med 35: 653-661.

Xin-Ping C, Song Q, LiuYi D, JiangNing Z 2006. Inhibitory effect of total flavone of Abelmoschus manihot (L.) Medik. on NMDA receptor-mediated current in cultured rat hippocampal neurons. Neurosci Res 55: 142-145. 